\title{
Students' Perceptions Of Cheating And Plagiarism In Higher Institutions
}

\author{
Daniel Owunwanne, Howard University, USA \\ Narendra Rustagi, Howard University, USA \\ Remi Dada, Howard University, USA
}

\begin{abstract}
There is a growing body of evidence that cheating and plagiarism are prominent problems in many universities. In informal conversations, it seems that different students perceive plagiarism differently. In this paper, we conducted a survey at Howard University to examine or to follow up with this growing trend. Specifically, team leaders in school of business were surveyed early in the Spring Semester of 2010 at a meeting and Freshmen were given the same survey at the end of the semester after their final examination. From the data generated in this survey, we determined the prevalence of cheating and the reasons why students cheat. This report is of great importance because it exposes the extent of academic dishonesty and, if successfully implemented, it could provide resources that would aid universities in solving the cheating problem.
\end{abstract}

Keywords: Cheating, plagiarism, $\mathrm{HBCU}$, undergraduates, graduates, questionnaire, survey

\section{INTRODUCTION}

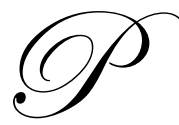

lagiarism and cheating are not clear-cut issues, despite the fact that most universities have written guidelines and codes of practice. In many instances, most students do not read the policies. Academic integrity is one of the many important attributes that all educational institutions strive to instill in their students. Assessment is an important aspect of the education process. This aspect has been emphasized more and more by accrediting bodies as well.

In 1964, Bill Bowers published the first large-scale study of cheating in universities. In his research, he conducted a survey of over 5,000 college students and found that 75 percent had engaged in one or more incidents of academic dishonesty. In more recent times, a research performed by Don McCabe for The Center for Academic Integrity at Duke University revealed that 70 percent of the 50,000 undergraduate students surveyed during 2002 to 2005, on some 60 campuses nationwide, reported cheating (McCabe, 2005).

Readily available documents and empirical data point out the prominent issue of cheating and plagiarism in many universities. Anecdotal and reported evidence indicates that there are many ways in which students cheat. Widespread use of the Internet in universities offers an important resource for doing research. Ease of use also makes it easier for students to cut and paste - a resource for students inclined to this type of behavior (Sheard, et. al., 2002). Ease of use to cut and paste also creates possibilities of an individual forgetting to cite his/her source, this is an incentive to cheat when trying to complete an assignment in a rush.

Even though students understand the need to demonstrate their knowledge of the subject matter, the process of assessment - administering the same examination in two sections of the course taught at different times and seriousness with which different infractions are dealt - causes different types of incentives and responses. Also, as stated earlier, different schools take different approaches to understand and address problems, like meetings with team leaders to understand the problems that students may have and implementation of honor code to partially address the problem, supplemented with addressing of problems with committees. It was with this in the background that a survey of students was conducted; first, team leaders and then the general freshmen students. Our primary objectives were to determine: 
1. if the survey of student team leaders is an accurate assessment of the student body

2. if students understand what academic misconduct (cheating) is

3. what proportion of the student body participates in academic misconduct of various types

\section{METHODOLOGY}

We developed a questionnaire survey that targets only undergraduate students at Howard University and we chose it because it provides us with multiple perspectives to analyze the educational levels and the prominence of academic dishonesty. The structure of this survey is designed to address the modern day environment; that is, easy access to information via the internet, emphasis on group projects, and influences of professional working environment on students. The questionnaire is comprised of questions regarding cheating, plagiarism on tests, and homework.

In an attempt to obtain an honest response from the students, the survey was conducted in a friendly environment - asking students to hand out the surveys to other students on campus, in the lunchroom and classrooms, and also reassuring the participants that their identity would remain anonymous. Classes were selected to represent junior and senior students' responses. To ensure that a student's response was not counted twice, students taking multiple surveyed courses were instructed to fill out only one questionnaire. After analyzing each survey, we eliminated the incomplete or incorrectly filled out surveys, leaving us with quite good number of usable and complete questionnaires. Students were instructed to indicate whether or not they had ever engaged in cheating or plagiarism activities. If the student had not had the opportunity to engage in one or more of the activities listed, he or she was instructed to respond accordingly.

\section{PREVALENCE OF CHEATING}

"Academic Dishonesty in Graduate Business Programs: Prevalence, Causes, and Proposed Action," is based on survey responses from 5,331 students at 32 graduate schools in the United States. The survey found that 56 percent of graduate business students - most of whom are pursuing MBA's - had cheated, compared with 47 percent of graduate students in non-business programs.

"Are the people who apply to business schools get-it-done, action-oriented people" who are more likely to bend rules to get ahead, or "is it something about the education or the culture of business schools that is to blame?", said Mr. Bailey, director of the executive development program at George Washington University School of Business.

This article points to the competitive nature of business schools and explains that students might adopt a "me first" attitude. "Graduate business students are more mature and their attitudes are probably more entrenched than those of undergraduate students." "Therefore, graduate students who have 'successfully' cheated as undergraduates and who have been exposed to questionable behavior in the workplace may be less responsive to exhortations to be ethical." Ms. Treviño added in an interview that among MBA students, "there's also a perception that their peers cheat more in a business school environment and that they'll be disadvantaged if they don't" (Sheard, et. al., 2002).

On the other hand, despite the differences between the graduate and undergraduate programs, we are still faced with the issue of academic dishonesty at the undergraduate level. "Many studies have investigated the extent of undergraduate student cheating, and although the results of these vary, the self-admission of cheating, in most cases, is alarmingly high" (Sheard, et. al., 2002). Alarming levels of cheating and plagiarism have been found in recent studies. Graham, Monday, and O' Brien performed a survey of 500 college students; the results state that $90 \%$ admitted to cheating.

Due to the large participation rate, students deem frequent cases of cheating acceptable. For example plagiarism is an act of academic dishonesty that is often carried out by students, but due to the ease of access of plagiaristic materials, students do not highly categorize plagiarism as a form of cheating, as opposed to sharing answers during an examination. In order to accurately analyze the prevalence of academic dishonesty, it is important 
to understand what students consider as cheating or plagiarism. One way of doing this is to have students rank on a scale of 1-10 the seriousness of different levels of cheating behaviors.

\section{ETHICS AND CHEATING}

Student cheating can be attributed to the known fact that the definition of cheating is unclear and ambiguous. A probable reason for the grey areas when discussing cheating can be linked to one's values and perception on ethics. Ethics is defined as an individual's personal beliefs about whether a behavior, action, or decision is right or wrong. Ethical behavior is defined as behavior that conforms to generally- accepted social norms. An individual's ethics and values are developed from a young age, structured within the family institution and can vary tremendously from culture to culture. For this reason, a code of ethics is formulated in every academic institution.

As stated earlier, Howard University has adopted a Code of Ethics to establish standards for all students regardless of culture, family surrounding and previously known social norms. The code of ethics ensures that every student has a fair and equal opportunity to gain and succeed from Howard University. Maintaining a "fair" playing ground is kept by placing emphasis on the academic infractions listed by Howard University's Academic Code of Student Conduct. The infractions included in Howard University's Student Code of Conduct define plagiarism and academic dishonesty. It continues by stating the penalties expected to occur if, by chance, a code is not honored. Despite these guidelines, students are still found cheating, not only at Howard University, but also at those universities across the country. Ultimately, the question is why do students cheat?

\section{WHY STUDENTS CHEAT}

It can be said that humans are creatures of nature. By natural instinct, humans have an innate ability to do whatever it takes to survive. Darwin's Origin of the Species explains it best - "Survival of the fittest" is the ideology that some students adopt while enrolled in school. Students cheat for a variety of reasons. Pressure from peers, lack of preparedness, unrealistic expectations and the emphasis on success are all logical reasons for cheating. The following is a more comprehensive list of reasons why students cheat.

In an academic setting where deadlines and exams are a major part of the curriculum, some students fail to prepare for their work. This instance may not necessarily be negligent or at the fault of the student. As business schools and undergraduates programs put more emphasis on extra curricular activities to better prepare students for the outside world, students may choose to place their academics low on their priority list. Since grades are not the only indication of how successful a student may be in their career, some students feel that they can get away with placing a higher priority on other activities not linked to academia. This thought can cause students to regularly be unprepared.

Furthermore, the pressing emphasis on higher grades for impressive transcripts, scholarship opportunities and possible Graduate Assistantships could encourage students to engage in cheating or plagiaristic activities.

As previously stated, the emphasis on grades and performance in academia may cause students to fall to academic dishonesty. Grades are not only used as a method to measure what a student has learned from a course, but it is also used as a measurement for granting awards, such as scholarship, internships and employment. Grades can be used as a motivator for students to achieve their highest performance. This notion provokes the need to succeed and win at any cost (survival of the fittest). The grading method used to promote success is also used as a motivation for students to cheat.

Although the rise of the information age has brought many advantages to the way work is conducted around the world, the phenomena also presents opportunities for corruption. The internet offers a myriad of information accessible anytime on our laptops, PDAs and Blackberry. Technology has made it easy to access the wealth of information available and has had a profound impact on the extent of cheating that occurs in universities. One could argue, therefore, that it is relatively easy to find information about a topic on the Internet and equally easy to copy and paste it into a report. Moreover, the advancement in telecommunication and electronics allow for 
students to store information anywhere. Information can be stored in cell phones or calculators can be connected to tiny devices that can be hidden in places such as an ear. As a result of easy access to information and sophisticated technology, students may be more likely to ignore their values and choose to partake in plagiarism and cheating.

Cheating is prevalent in graduate students. Astoundingly, 56\% of MBA students have admitted to cheating. The numbers are higher for those MBA students who have been exposed to the professional work place. In analyzing the high statistical data for cheating among MBA students who have been exposed to the workplace, academic pressure is equivalent to social pressures. Success in the work place is attained through adhering to the "bottom line". Success driver's in the workplace include achieving soaring profits, staying under budget and creating lasting impressions to move higher up the corporate ladder. Many students who came from the workforce have found that "strategic positioning" (cheating) is the only way to survive because the nature of the workforce permits such social norms.

If preventive measures are weak within an academic institution, students are more apt to cheating. When students cheat once and have gotten away with it, the chances of that student cheating again are very likely. The students repeat attempt to cheat is motivated by the ease of cheating and the low detection rates. A student's confidence in cheating without consequences leads to an increase of academic dishonesty amongst educational institutions.

The way a class is structured and how the instructor presents the curriculum can influence cheating in the classroom. A student may feel compelled to cheat if the course taken is of little interest to that student. This concept is further explained when the student feels as though they may never need the subject matter to succeed in their future lives. To some students, it is illogical to study hard and subject oneself to tireless effort when an easier way to complete the course is presented. Moreover, when a student takes little interest in their professor, a slightly different reasoning is applied. When a student has little respect for their professor because they feel as though some aspect of the course is unfair, cheating is likely to occur. A student finds justification in cheating in a class where they feel that the instructor is unfair and the subject matter is of little relevance to their future aspirations.

When asked, "If everybody were to jump off the bridge, will you jump too?", one student replies, "Well, yes. There must be a logical reason why everybody has chosen to jump off the bridge. If there is something down there that I can benefit from, I would be at a clear disadvantage of receiving it." This thought is a possible common thought present amongst students. When students know that other students are benefiting from cheating, some students are more compelled to cheat. Howard University's Code of Student Conduct attempts to ensure that all students are given a fair and equal opportunity to gain and succeed from their academic experience. However, this can be seen as a flaw in the academic system. Since it is proven that cheating takes place at all levels in academia, a fair and equal opportunity is then impossible to achieve and unrealistic to comprehend. Those students who are aware of this find justification in their cheating.

It is difficult to clearly define the word "cheating". As mentioned before, cheating is associated with ethics, values and an individual's subjective perception of what is considered right or wrong. Failure to identify a clear definition of cheating can distort what the student considers as academic dishonesty. To correct this diluted conception, universities place a code of ethics that set standards for which students and faculty are expected to adhere to. However, policies may or may not be widely communicated, understood, and followed. It is the responsibility of the institution to implement and ensure that their code of ethics is known, accessible and understood by the student body.

The blurred conception of what cheating consists of has resulted in confusion among many students. This confusion is easily converted into an implicit excuse for students as they cheat during school, which in turn can also provide further justification to students' cheating. The many valid reasons that explain the "why" behind student cheating have caused a large participation rate of students; many who deem frequent cases of cheating acceptable. For example, plagiarism is an act of academic dishonesty that is often carried out by students. Yet, due to the ease of access of plagiaristic materials from the internet, students do not highly categorize plagiarism as a form of cheating, as opposed to sharing answers during an examination. To accurately analyze the prevalence of academic dishonesty, it is important to understand what students consider as cheating or plagiarism. One way of doing this is to use a scale 
and have students rank the seriousness of different levels of cheating behaviors.

\section{CONTROLLING CHEATING}

At Howard University, the Academic Code of Student Conduct has some sections attached to it regarding the administration code and procedures that take place if a student is accused of cheating, as well as a description of the penalties. The penalty for being caught cheating at Howard ranges from receiving no credit for the assignment or course in which the infraction took place to suspension from the University. Despite these seemingly harsh penalties, many students still cheat. One qualitative study (McCabe and Pavela, 1997) determined the perspectives of how to reduce cheating in the classroom from a student's perspective and from a faculty perspective. From their study, it is evident that students and faculty share many similar views on how to reduce classroom cheating, such as the importance of academic integrity, clear and well-defined policies and expectations. Some schools, such as Howard University, do little more than telling students that the school honor code is somewhere in their student handbook. Other institutions use orientation sessions, initiation ceremonies, as well as other formal policies, to convey a tradition of honor and expectations for incoming students (McCabe 2001).

Controlling cheating has become much more different due to the technology students have available to them. According to a recent study, 17 percent of students use the internet to cheat on assignments. Examples of cheating through technology are prevalent in today's society. At the University of California in Los Angeles, a student uploaded his class notes into a handheld electronic device and attempted to read them in class. Another example at the University of Nevada in Las Vegas, students photographed test questions with their cell phone cameras and sent them to classmates outside the class who then looked up the answers and text messaged them back to the test takers. This example shows that it is harder than ever to determine cheating and, furthermore, to stop it from happening. How does an institution, such as Howard University, control cheating?

Professors attempt to eliminate cheating by placing restrictions on what types of electronics are allowed in classrooms, especially during exams. Many teachers do not allow any type of electronic devices in class and ask students to turn off all cell phones and other electronics. Just as recently as 2004, at the University of Maryland, accounting professors in the MBA program took part in a "sting" operation after several students in the class accused other students of cheating. The team of professors got together and posted an answer key to the final exam on the course website. During the examination, the professors ignored the sounds of cell phones and other electronics during exam. After the grading was finished, they found that twelve students had the same exact answers as those posted online. When confronted with these results, many of the implicated students admitted to cheating and others were convicted of cheating by a group of students and professors. Those students received a grade in the class of "failure due to academic dishonesty." The resulting action of this incident was that all electronics were banned, (Read, 2004).

This example shows that many professors are finding out the hard way that the honor code is not enough. In fact, some are taking more proactive measures to insure that cheating is being watched under a close eye. At the University of Maryland College Park, if any student is caught using a cell phone or electronic device, they automatically fail the exam. At the University of California Berkeley, each student receives a randomly-generated multiple choice examination so that no two students will have the same exam. This means that any student who tries to get around their no electronics policy will not be able to transmit answers to other students. The University of Maryland believes in a "modified honor code" where a professor is required to proctor all examinations and watch for forms of low tech and high tech cheating (Read 2004).

Contrary to the notion of a "modified honor code," Dartmouth College and other colleges have endorsed more liberal codes of conduct that expect students to be responsible for his/her own academic integrity. This type of code allows for professors to make their decisions regarding guidelines for monitoring tests. Donald L. McCabe, a professor of organization management at Rutgers University at New Brunswick who founded the Center for Academic Integrity, once stated, "I'm a big believer that what we need to do is engage students in a dialogue about cheating." He says, "The research I've done suggests that honor codes have reduced the level of cheating almost everywhere they've been applied" (Read, 2004). Applying an academic honor code in which students are encouraged to participate in dialogue about cheating may be another affective tactic against classroom cheating. 
Expanding on the idea of academic honor code, (Dick et. al., 2002) explain that one way to control cheating is to reduce cheating by cultural change. According to this study, improving education culturally will correspond with a reduction in cheating because students will no longer want to cheat. Students were found to be less likely to cheat on their work - defined as assignments, papers, and exams - if they understood the educational goals of this work. If there is a good relationship between the teacher and the student, and students understand the learning process and the reasons and goals behind their assigned work, they will be less likely to cheat. Students, in turn, will be motivated to complete work for the educational benefits, rather than solely for the grade (Dick et. al, 2002).

McCabe determined from their research that the cheating is most effectively addressed at the institutional level. They believe that while an honor code does reduce cheating, it is not enough. Academic institutions should consider a way of building an "ethical community that includes clear communication of rules and standards, moral socialization of community members, and mutual respect between students and faculty, and one that extends certain privileges to its students (e.g., non-proctored exams, self-scheduled exam, etc.)" In building this ethical community, academic institutions could create a "hidden curriculum" in which students receive informal instruction regarding ethical issues and are encouraged to participate in discussions involving ethics and their institution, (McCabe, et. al., 2001).

\section{DATA AND ANALYSIS}

As stated earlier, undergraduate students were surveyed using a simple questionnaire with 10 questions; first five were yes/no questions and later five involved Likert items to choose one of five choices from Strongly Disagree to Strongly Agree. Twenty-four student team leaders answered the questions and 177 students answered from two sections. Seven answered all "yes' in the first five questions and 104 answered 'no' to all questions.

The paper started with a curiosity as to whether the use of a select group (not a random sample) to draw inferences about the general population is appropriate or not. Proportion of students answering 'yes' in the first five questions was compared with the proportion of team leaders answering 'yes.' The initial thought was to exclude students who answered yes to all and no to all. Thus, a comparison was made using the $t$ test (summarized in Table 1). For comparison of students with mixed responses to responses of team leaders, the answers are significantly different for only the second question; i.e., "Have you turned in information from the Internet with sourcing it?" Results are significant at $\alpha=.05$. Since the null hypothesis is

$\mathbf{H}_{\mathbf{0}}$ : proportion of team leader response - proportion of all students $=0$.

If the alternative hypothesis were:

$\mathbf{H}_{\mathbf{a}}$ : proportion of team leader response - proportion of all students $<0$,

The difference is significant at even $\alpha=.025$ that team leaders do it even more than the students who had mixed response.

If we take all students into consideration, which is the appropriate group, the differences are significant for the second question as well as the third; i.e., 'Have you copied someone's answer for an out-of-class assignment?' Again, if the test were one-sided, one would conclude that team leaders do it even more than the general student body.

Table 1: Results of t-test Comparing Proportion of Respondents Saying 'Yes' between Team Leaders, Students Mixed Responses, and All Students

\begin{tabular}{|l|c|c|c|c|}
\hline \multicolumn{1}{|c|}{ Question } & Mixed response & \multicolumn{2}{|c|}{ All } \\
\hline & t & p-value & t & p-value \\
\hline 1. Have you cheated on an examination at any point during college? & 1.53 & 0.13 & 1.31 & 0.19 \\
\hline 2. Have you turned in information from the Internet without sourcing it? & -2.08 & 0.04 & -2.22 & 0.03 \\
\hline 3. Have you copied someone's answers for an out of class assignment? & -1.35 & 0.18 & -2.33 & 0.02 \\
\hline 4. Have you given a student in a later section information about an exam? & 0.60 & 0.55 & -0.58 & 0.57 \\
\hline 5. Have you received exam information from a student in an earlier section? & 0.24 & 0.81 & -1.26 & 0.21 \\
\hline
\end{tabular}


If we look at the absolute percentages in Chart 1, it is appalling that such a high percentage of students are involved in some type of academic misconduct. What is also interesting is that a relatively smaller percentage of them actually cheat on the examination as compared to a much higher percentage that is involved in academic misconduct of the type where the administration and professors are not laying any emphasis; i.e., independent and/or group research. What is equally surprising is the high percentage of students who consider cheating, while it is not "cheating"; i.e., information on previous examination. Professors should either design separate examinations or the examination should be conducted at a common time, which is the new trend at this school.

Chart 1: Percentage of Team Leaders and Student Body Answering 'Yes'

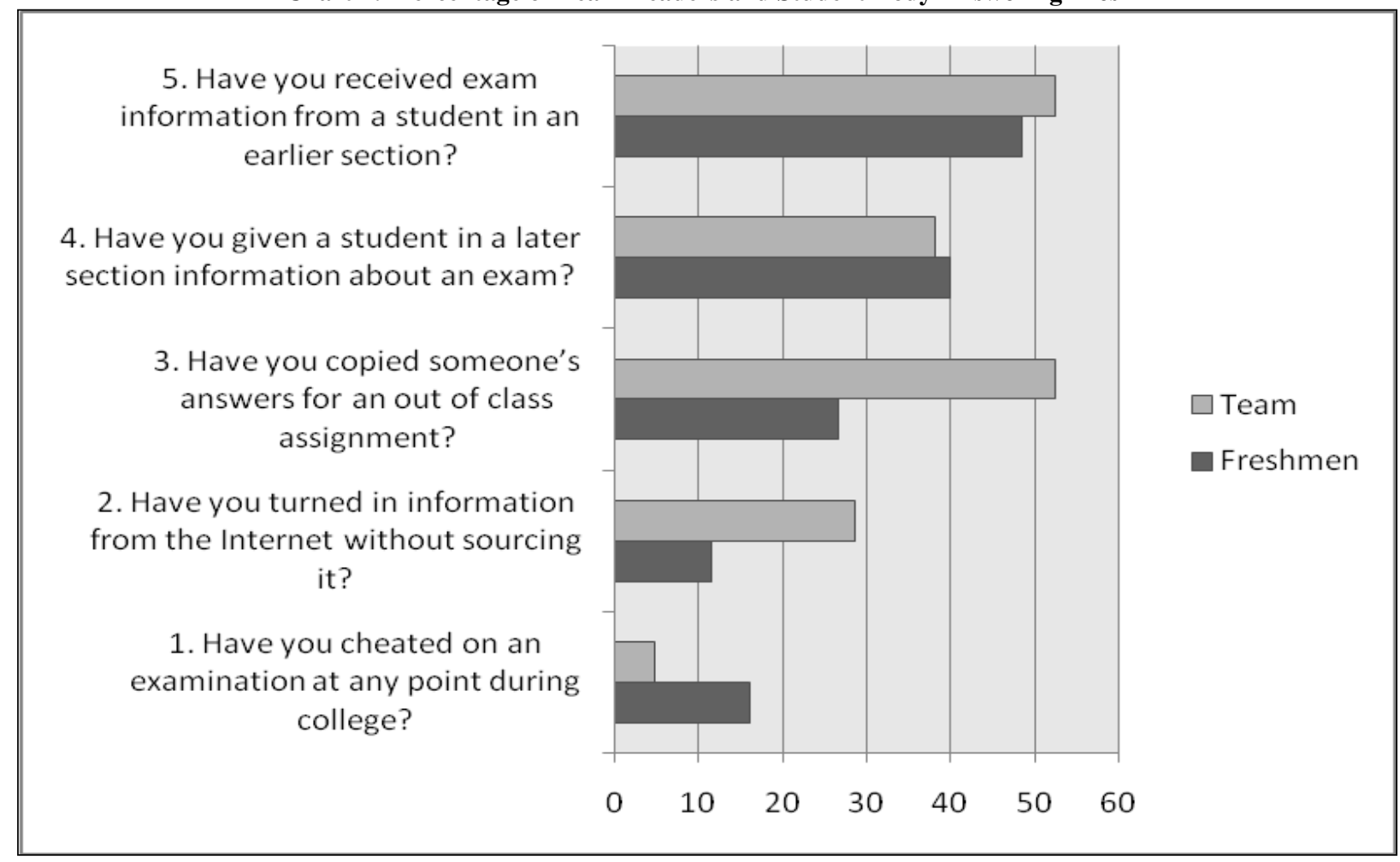

Students were asked the following questions to which they were to respond on a Likert scale with "Strongly Disagree" on one end and "Strongly Agree" on the other. The following five questions were asked:

Cheating includes:

1. submitting work completed as a assignment in a prior class

2. giving a friend exams you took in a prior class in a previous semester

3. getting help from a friend to complete an out-of-class assignment that was supposed to be done independently

4. giving help to a friend to complete an out-of-class assignment that was supposed to be done independently

5. getting instruction from the web to complete an out-of-class assignment without quoting the source

It would be expected that most students would have selected "Strongly Disagree" as their response to the first two questions. All classes have different emphasis and one could use the same issue and look at it from different perspectives in different courses. Similarly, it would be expected that students would have selected "Strongly Agree" to responses for the last three questions. It was surprising to observe that distribution of responses was not as skewed. As shown in Chart 2, almost $40 \%$ strongly disagree that "giving help to a friend to complete an out-of-class assignment that was supposed to be done independently" is not cheating. 
Chart 2: Views of Students on What "Cheating Means to Them'

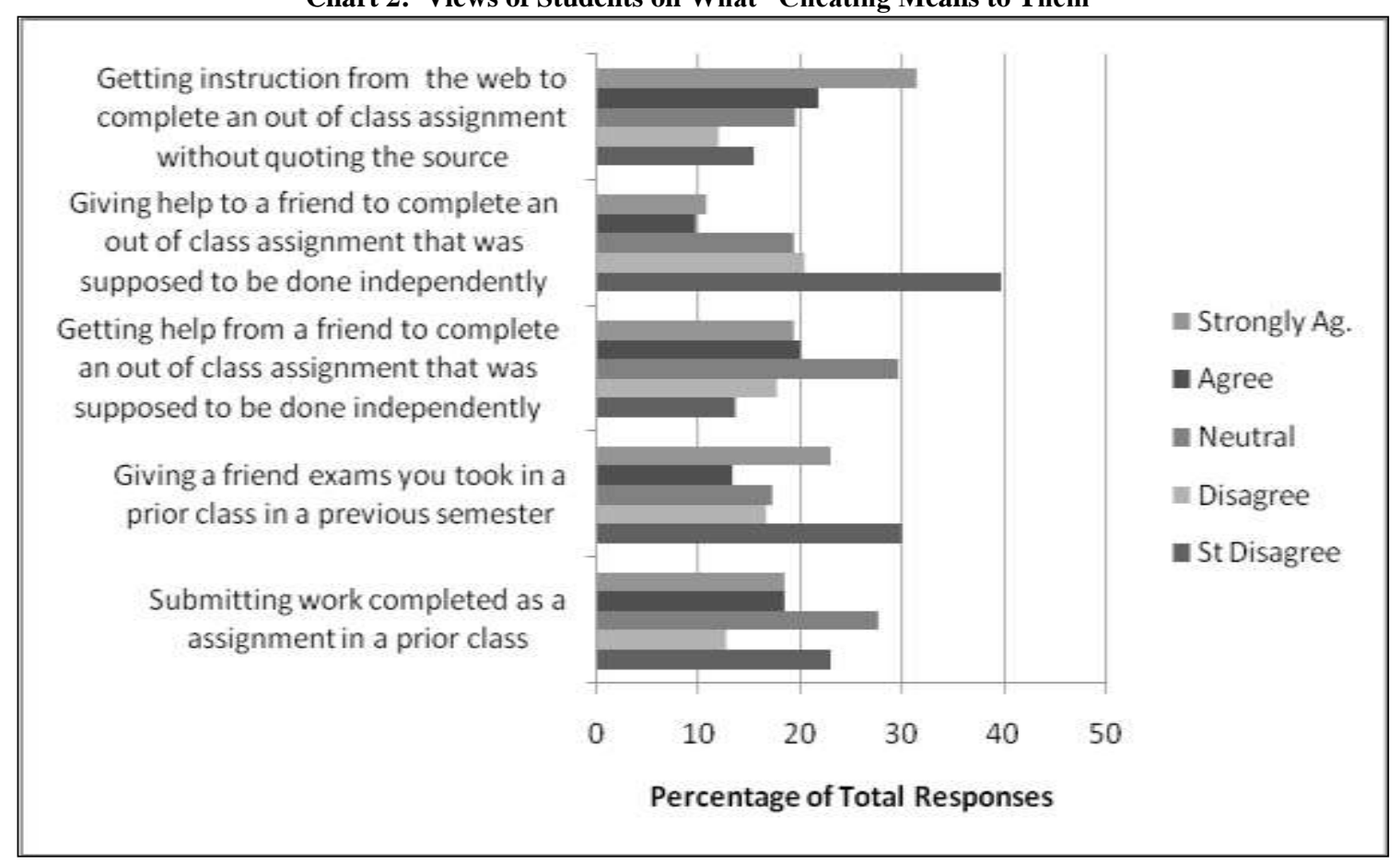

To compare responses of the Freshmen class as a whole and team leaders only, responses to the first two questions for "Strongly Disagree" and "Agree" were combined. Proportion of students giving these responses as a percentage of the total number of students was compared using the $t$ test. Results are summarized in Table 2 . With such high p-values, it is clear that there is no significant difference between responses of team leaders and all students.

Table 2: Results of t-test Comparing Proportion of Respondents Saying 'Strongly Disagree' and "Disagree" between Team Leaders and All Students

\begin{tabular}{|l|c|c|}
\hline \multicolumn{1}{|c|}{ Question } & t & pll \\
\hline Submitting work completed as a assignment in a prior class & -0.75 & 0.45 \\
\hline Giving a friend exams you took in a prior class in a previous semester & -1.09 & 0.28 \\
\hline
\end{tabular}

To compare responses of the Freshmen class as a whole and team leaders only, responses to the remaining three questions for "Disagree" and "Strongly Disagree" were combined. Proportion of students giving these responses, as a percentage of the total number of students, was compared using the t test. Results are summarized in Table 3. Also in these cases, with such high p-values, it is clear that there is no significant difference between responses of team leaders and all students.

Looking at the charts, the response to one particular question; i.e., "cheating includes giving help to a friend to complete an out-of-class assignment that was supposed to be done independently" was surprising, especially when you look at this response in light of their response to "getting help from a friend to complete an out-of-class assignment that was supposed to be done independently," for which a much larger proportion answered that it is cheating. This may be a good case for the discussion on ethics. 
Table 3: Results of t-test Comparing Proportion of Respondents Saying 'Agree' and "Strongly Agree" between Team Leaders and All students

\begin{tabular}{|l|c|c|}
\hline \multicolumn{1}{|c|}{ Question } & All & p-value \\
\hline \multicolumn{1}{|c|}{} & \multicolumn{1}{|c|}{ t } & 0.63 \\
\hline $\begin{array}{l}\text { Getting help from a friend to complete an out of class assignment that was supposed } \\
\text { to be done independently }\end{array}$ & 0.48 & 0.13 \\
\hline $\begin{array}{l}\text { Giving help to a friend to complete an out of class assignment that was supposed to } \\
\text { be done independently }\end{array}$ & -1.52 & 0.10 \\
\hline $\begin{array}{l}\text { Getting instruction from the web to complete an out of class assignment without } \\
\text { quoting the source }\end{array}$ & 1.66 & \multirow{2}{*}{0} \\
\hline
\end{tabular}

\section{CONCLUSION}

As stated earlier, this started with exploration of whether team leaders were giving a good picture of what students think about cheating. When they were surveyed, the responses did not sound too logical and it was then decided to survey as much of the freshmen class as possible. Thus, surveys were distributed in final examination for two courses (which were conducted at the same time). One of these was taken primarily by Freshmen and the second one primarily by Juniors. Completion of the surveys was not mandatory and students could choose to complete the survey after completing their examination. Since it was not possible to separate surveys from two groups, a comparison of the two groups cannot be made.

In response to the question of whether the team leaders' views reflect the views of the general student body, it appears that they do on most issues. However, what was surprising is that team leaders were more involved in academic misconduct for work completed outside the classroom. When absolute percentages are considered, it is appalling that such a high percentage of students are involved in some type of academic misconduct. What is also interesting is that a relatively smaller percentage of them actually cheat on the examination as compared to a much higher percentage that is involved in academic misconduct of the type where the administration and professors are not laying any emphasis; i.e., independent and/or group research. What is equally surprising is the high percentage of students who consider cheating while it is not "cheating"; i.e., information on previous examination. Professors should either design separate examinations or the examination should be conducted at a common time, which is the new trend at this school.

\section{AUTHOR INFORMATION}

Dr. Daniel Owunwanne is an Assistant Professor at Howard University, Washington DC, USA. His areas of research interest are Data Interoperability in Federated Databases, Software Fault Tolerance, and Data Transmission. Dr. Owunwanne has presented many papers in these areas of his research interest and as well as in an interdisciplinary areas in both national and international conferences. He has also published many papers in conference proceedings and refereed journal articles. He teaches Databases, C++, Software Design, Data Communications and Networks, Management Information Systems, and Systems Analysis and Design.

Dr. Narendra K. Rustagi is Director of the Global Business Center at the School of Business, Howard University. $\mathrm{He}$ is also a tenured Professor and has been very active in several departmental and school-wide committees, which include serving as co-chair of the university-wide Task Force to suggest policies for distance learning, and chair of School-wide committees to develop curricula for MBA concentrations in E-Commerce and Supply Chain Management. Dr. Rustagi was also consulted by two universities internationally in enhancing their programs. He earned undergraduate and master's degrees from University of Delhi, India, and earned Master of Applied Statistics and Ph.D. degrees from the Ohio State University.

Mr. Remi Dada received his Bachelor of Science in Architectural Studies degree from the University of Illinois Urbana Champaign in 2006. He spent the next three years practicing Architecture in Chicago under Cordogan Clark and NIA architect. Remi is currently a 2011 MBA candidate at Howard University, concentration is Marketing and Supply Chain Management. 


\section{REFERENCES}

1. $\quad$ Academic Code of Student Conduct. 1987. Retrieved from http://www.howard.edu/policy/academic/codeofconduct.htm

2. Coleman, Natasha, Mahaffey, Tom. 2000. Business Students Ethics: Selected Predictors of Attitudes towards Cheating. Teaching Business Ethics. 4:2, 121-136

3. Dick, Martin, Shead, Judy, Bareiss, Cathy, Carter, Janet, Joyce, Donald, Harding, Trevor, Laxer, Cary. 2002. Addressing Student Cheating: Definitions and Solutions. Working group reports from ITiCSE on Innovation and technology in computer science education. 172-182.

4. Graves, Sharon M. 2008. Students Cheating Habits: A Predictor of Workplace Deviance. Journal of Diversity Management. 3:1, 15-22

5. Klein, Helen A., Levenburg, Nancy M., McKendall, Marie, Mothersell, William. 2006. Cheating during the College Years: How do Business School Students Compare? Journal of Business Ethics.72: 197-206

6. Lambert, Eric G., Hogan, Nancy Lynne., Barton, Shannon M. 2003. Collegiate Academic Dishonesty Revisited: What Have They Done, How Often Have They Done It, Who does It and Why Did They Do It? Economic Journal of Sociology. ISSN 11983655

7. Mangan, Katherine. 2006. Survey Finds Widespread Cheating in M.B.A. Programs. The Chronicle of Higher Education. Retrieved from http://chronicle.com/daily/2006/09/2006091902n.htm.

8. Martin, Dick, Shead, Judy, Bareiss, Cathy, Carter, Janet, Joyce, Donald, Harding, Trevor, Laxer, Cary. 2003. Addressing student cheating: definitions and solutions. ACM SIGCSE Bulletin. 35:2, 172-184.

9. McCabe, Donald L, Pavela, G.R. 1997. Ten Principles of Academic Integrity. The Journal of College and University Law. 24: 117-118.

10. McCabe, Donald L., Trevino, Linda Klebe, Butterfield, Kenneth D. 2001. Cheating in Academic Institutions: A Decade of Research. Ethics and Behavior. 11: 219-232.

11. McCabe, D. 2005. Levels of cheating and plagiarism remain high. The Center for Academic Integrity. Retrieved from http:// www.academicintegrity.org/cai_research.asp.

12. McCabe, Donald L., Butterfield Kenneth D., Trevin, Linda Klebe. 2006. Academic Dishonesty in Graduate Business Programs: Prevalence, Causes, and Proposed Action. Academy of Management Learning \& Education. 5:3, $294-304$.

13. McDowell, Liz, Brown, Sally. 2001. Assessing students: cheating and plagiarism. The High Education Academy. Retrieved from http://www.heacademy.ac.uk/assets/York/documents/resources/resourcedatabase/id430_cheating_and_plag iarism.pdf

14. Read, Brock. 2004. Wired for Cheating. Chronicle of Higher Education. 50:45. Accessed via Academic Search Premier Database.

15. Sheard, Judy, Dick, Martin, Markham, Selby, Macdonald, Ian, Walsh, Meaghan. 2002. Cheating and plagiarism: perceptions and practices of first year IT students. ACM SIGCSE Bulletin. 34:3, 183-187.

16. Smith, Kenneth J., Davy, Jeanette A., Rosenberg, Donald L., Haight, G. Timothy. 2009. The Role and Motivation and Attitude on Cheating Among Business Students. Journal of Academic and Business Ethics. 1:12-37.

17. Chi Square Two Sample http://www.itl.nist.gov/div898/software/dataplot/refman1/auxillar/chi2samp.htm 